\title{
Why Wall? A Kleinian Reading of the Israeli-Palestinian Resistance to Politics
}

Maya Mukamel

Tel-Hai Academic College

The present work explores the separation barriers built by the Israeli government and military as products and producers of asymmetries of power between Israelis and Palestinians; and, at the same time, as products and producers of discourses characterized by the naturalization of evil. In such discourses, embedded in both Israeli and Palestinian politics, evil is singularized as a unique cultural property of the adversary. Violence and aggression on the part of the national adversary are then perceived as a sign of a primitive morality, detached from political and historical circumstances; and the violence of each party is justified as a defensive war on the "evil" other. A return to Melanie Klein enables one to trace these dynamics, and to approach the complexities of the play of representations, projections and identification that affect, and are affected by, Israeli and Palestinian management of the conflict. The last section of this paper offers a critical reading of Jacqueline Rose's analysis of the Zionist psyche, a reading that is at the same time an affirmation of Rose's extrapolation of Kleinian thought into the political arena. This section raises fundamental questions about the perspective of the cultural analyst, and calls for incorporation of some essentials of a psychoanalytic stance into the practice of cultural critique.

Maya Mukamel is a clinical psychologist and a facilitator of conflict group encounters. She is a co-founder and an active member of Psychoactive-Mental Health Professionals for Human Rights. She teaches in The Graduate School of Creative Art Therapies at the University of Haifa. Her writings are on the history and philosophy of psychoanalytic ideas, gender and psychotherapy, Israeli occupation and the Israeli-Palestinian conflict. Her current research is on the concept of dissociation and its application in psychoanalytic practice.

\section{On the Israeli Side of the Wall: Politicization of Might}

The "seam zone" is an Israeli-demarcated strip of land, extending over several hundred square kilometers east of the green line, bounded by a wall and a fence which separate it physically and legally from the West Bank (Arieli 326). Former IDF Colonel Shaul Arieli, who has studied the fence issue extensively on behalf of the Council for Peace and Security, notes that the idea that the wall will demarcate the borders between Israel and Palestine began to prevail in the Israeli political arena after the second Intifada erupted in late 2000 (327). Several politicians gave voice to the notion that the wall should demarcate the limits of 
the eastern territories under the sovereign rule of the State of Israel, which are currently undefined by borders.

Tsipi Livni, while serving as minister of justice, said that the separation fence would constitute "the future border of the State of Israel," and that "the High Court of Justice, in its rulings over the fence, is drawing the country's borders." ${ }^{1}$ Ehud Barak, too, when serving as minister of defense in the government of Ehud Olmert, noted that "when we build a fence it is clear that there are areas that are beyond the fence, and it is clear that in the permanent accord... these areas that are beyond the fence will not be part of the State of Israel"2. Prime Minister Sharon also supported the idea that the wall will eventually become the Israeli state's border, and Ehud Olmert agreed: "The direction is clear, we are moving toward separation from the Palestinians, towards the demarcation of a permanent border of Israel". ${ }^{3}$

The notion that the fence should implement a political policy of separation would have implied that its path would follow the "Green Line," i.e., the unofficial border demarcated as an Armistice demarcation line after the 1967 war. This was not the case.

Objections to the conception of the wall as a mark of political separation were expressed by those who opposed the construction of the barrier due to the belief that such barrier would set the boundary for a "terrorist state" that would arise on the other side (328). Among the objectors were the Chief of Staff Shaul Mofaz and his deputy Moshe Ya'alon. The latter opposed the wall as a sign of defeatism and military passivism (328).

The second Intifada and the economic reality eventually led Prime Minister Ariel Sharon to rule for the construction of the fence (328). Sharon handed the task to the IDF and the defense establishment, who did not want it (328). The path of the wall and fence has thus been subject to profound disputes among their architects. The political echelon decided on a route of the fence ranging deeply into the territory of the West Bank (beyond the Green Line) (330). However, there were High Court petitions submitted against it (329). Whereas Sharon supported pushing the fence eastward, the chief of staff at the time, Gabi 
Ashkenazi, sought to move the fence westward (332). Since the IDF was handed the task of the construction of the barrier, it was unable to remain disengaged in matters concerning its path, and the unavoidable resulted - the politicization of the military system (332).

The politicization of the military has far-reaching implications for the political as well as for the military establishment. Arieli observes that whereas the IDF's declared principle is to decrease the "offensive component" and the "friction with Palestinians" - in effect, the IDF actually intensified its intervention with Palestinian life, "despite the fact that the fence provided a reasonable solution for preventing the uncontrolled entry of Palestinians and vehicles into Israel" (332). The rest is recent history - hundreds of roadblocks, preventing movement between Palestinian communities in the West Bank, continuous friction with the IDF soldiers at the checkpoints, and a traffic regime that significantly changes Palestinian everyday life - all these are an inherent part of the IDF control of Palestinian movement in the West Bank.

Furthermore, writes Arieli, the logic of the fence built by the IDF counters the logic of security, according to which Palestinian lands should have been separated from the seam zone wherever possible. Instead, lands were separated from their owners (339). Arieli told a Ha'aretz interviewer: "The desire to include more territory within the confines of the fence than is practically possible has resulted in a situation where the settlement blocs are left outside of the fence while other blocs remain vulnerable and do not receive protection. In addition, exorbitant sums of money have been pumped into infrastructure and fences that were supposed to follow a route that was impossible to complete."4

\section{Naturalization of Threat: The Continuation of War by Other Means}

The wall, then, is a symptomatic substitute for a missing border, which is a failure of political self-determination. The inability to stabilize a policy regarding the border, and the de-facto management of the "seam zone" by the IDF and the security establishment can be said to turn the "seam zone" into a zone of 
struggle, not only between terrorists and innocent civilians, but also between different ideas of an Israeli sovereignty.

Multi-faceted and conflicting notions of what an Israeli state is, and struggles around the idea of the State that should guide the demarcation of its borders play a vital role in the indecisiveness regarding the wall's path and role. "Self-determination" means different things for different political and social players, and there is a related difference in the notions of "border" implied in their various discourses (Mukamel, 2009). In the discourse of the extreme political right-wing, the relation to the Holy Land is determined in the bible - the Land of Israel is promised to the Chosen People. The borders of the state are thus divinely pre-determined and unchangeable, marking the restoration of an ancient Jewish rule over Great Israel, from the Jordan River to the Mediterranean Sea. For the political center, self-determination means the right of Jews for sovereign rule, and thus the borders are markers of the territory in which such rule is legitimate. Since borders are not sacred, they can compromise the notion of Great Israel and be politically negotiated and determined. For the extreme political left-wing, self-determination is detached from race, religion and ethnicity, and thus the borders should serve as demarcation of a democratic, non-ethnic rule, in which Israelis and Palestinians have equal citizenship (bi-national state), or, more generally, a rule in which all citizens, regardless of nationality, religion etc., have equal rights (a state for all its citizens).

The way the wall and fence are designed, their path and their continuous military management, are justified as "security needs." This phrasing forecloses not only public discourse on the acts of state in the West Bank and Gaza, but also a political debate on the politicization of the military and on the borders of the State of Israel. The notion of political separation thus gave way to military discourse not only for security reasons. It is not only because of security threats that separation failed. The political notion of separation between Israel and Palestine does not translate itself into separation de-facto, partly because various forms of Israeli national identity resist it. This resistance to the political notion of separation leans on a naturalization of Palestinian terror as evil, and on its 
correlate - an experience of Israel's moral superiority that justifies its military actions.

Mainstream politicians of the center and political right express a fundamental belief in the moral superiority of the Israeli-Jewish society vis-à-vis terror as a natural evil, i.e., as detached from political and historical context. Several central players in Israeli politics have expressed these views on different occasions.

In an interview for Ha'aretz, Livni said she is convinced that IDF soldiers will never intentionally hurt women and children and that this creates a fundamental moral difference between "us", Israeli Jews, and "them," Palestinians. Her words express a conviction that Israelis' morals are superior to those of Palestinians, and that the actions of the IDF are fundamentally justified and morally impeccable. ${ }^{5} \mathrm{~A}$ similar conviction is expressed in Ehud Olmert's statement in the memorial service for Israeli victims of terror, 2005:

In this time of communion with our citizens who have died in hostile attacks, I cannot refrain from imagining the horrific sights of terrorist bombings in Jerusalem, to which I bore witness. I cannot refrain from thinking how deep is the moral abyss between our values and the values of our enemies. We do not negate the right of any nation or any state to live in peace. We are fighting only to defend ourselves and thwart aggression against us. We are making every effort to target [our attacks] and reduce the injury of innocent people. ${ }^{6}$

In a more recent memorial to victims of terror, ${ }^{7}$ Prime Minister Binyamin Netanyahu said:

The atrocities of the terrorists against our people know neither moral nor political limits. ${ }^{8}$ Their cruelty and hatred are insatiable. There is one thing common to all these murderers: they wish to erase the Jewish people from the face of the earth and to uproot our people from our land, the Land of Israel. They will not succeed. We are here in Jerusalem and we will remain in Jerusalem, our 
united capital and the Holy City of the Jewish People throughout history. ${ }^{9}$

The belief in the moral superiority of Israel is related to a belief in the absolute morality of the IDF. Halperin et al. note that "Even in present times, political and military leaders alike refer to the IDF as the most moral military force in the world." They cite the statement of former Prime Minister Ehud Olmert at the opening of a cabinet meeting after seven members of a Palestinian family had been killed: "the IDF is the most moral military force in the world... it has never implemented a policy of hurting civilians and does not do so presently either" (66).

The army, too, introduces itself with a humanitarian self-image. The official website of the IDF reads:

The design, construction and operation of the Security Fence aim to balance the imperative to protect innocent lives from terror with the humanitarian needs of the local Palestinian population. Israel's government realizes that the construction of the Security Fence can introduce hardship into the lives of innocent Palestinians and regrets those hardships. All attempts to minimize such problem have been and will continue to be made. ${ }^{10}$

A message of equality and symmetry is conveyed, a concern for innocent lives of both Israelis and Palestinians, while the fence is introduced as a necessary minimal defense against life-endangering terror. The main objective of the fence, the statement reads, is a protection of Israeli citizens from terror. The fence "can introduce hardship" into the lives of innocent Palestinian citizens - as though it does not introduce, de facto, the conditions which endanger Palestinian individual and civil life. It is as if the problem of military rule over civilians is one of lack of human kindness vis-à-vis "humanitarian needs." The irony of this humanitarian image can be seen in various checkpoints along the separation fence and wall, where concern for the needy is expressed by assigning separate lanes and desks. [Photograph - "humanitarian lane"] 
The path of the wall and its management are thus founded not only on the imperative to defend Israeli society, but also on the perception that the terror Israel faces is a singular and natural evil; that Palestinian hate and violence towards Israelis is an effect of their terrorist nature. Thus, Israel's violence against the Palestinians is justified as self-defense, i.e., morally impeccable.

\section{On the Palestinian side of the Wall: Militarization of Right}

This dynamics nourishes an asymmetrical struggle in which Israel launches daily attacks against the Palestinian population on the eastern side of the wall, "and Hamas strikes at Israeli civilian population concentrations in the Gaza region with rockets and mortars - for which Israel still lacks an effective defensive or offensive response" (Arieli 193). It also nourishes another dynamic, in which Israelis are perceived as inherently evil, immoral and principally unwilling to reach an agreement.

Ramadan Shallah, Secretary General of the Islamic Jihad expresses, in a rare interview, a profound disbelief in Israel's intention to resolve the conflict. "The Palestinian struggle started with the idea of a one-state solution, then made every concession for a two-state solution. And nothing," he said (Atran and Axelrod 3). "You will not find any political faction in the future that will accept a two-state solution based on Israeli security needs. We see that a sovereign and independent Palestinian state is impossible under such conditions" (4). Since the Israeli idea of a two-state solution does not allow for Palestinian sovereignty, and since a one-state solution is not foreseeable, the solution is armed resistance: "I see no end to the struggle until Israel is defeated" (4).

On the one hand, Israel is perceived as the only obstacle for a political settlement. On the other hand, there is complete disavowal of politics as such as a means for resolution. Shallah says: "We aren't the guilty party to be asked for a solution because we didn't create the problem." Negating the possibility of a political discourse and arrangement, in favor of sacred morals, Shallah states that 
Our sacred duty is to fight, to resist occupation of our sacred land and change the conditions of our people. That is our duty, our sacred duty. Others, like Fatah, have maps and negotiations. We resist. (Atran and Axelrod 7)

The political option is negated both out of disappointment and rage, and out of a denial of a possibility of negotiation, which would mean political recognition of Israeli sovereignty.

A more ambivalent stance can be found in the words of Abu Marzouk, Deputy Director of Hamas's political bureau. In a recent and rare interview for The Forward, Abu Marzouk described the notion of hudna, or truce, with Israel. ${ }^{11}$ Hudna will establish a relationship between the two nations, which is "better than war and better than the continuous resistance against the occupation. And better than Israel occupying the West Bank and Gaza, making all these difficulties and problems on both sides." On the one hand, there is a willingness to negotiate and thus to politically engage with the State of Israel. On the other hand, such engagement would not mean recognition of Israeli sovereignty. Hudna is thus an agreement on a temporary suspension of violence, not on political recognition. When confronted with the "concerns that Hamas's goal during a hudna would remain the destruction of Israel as a state and that a truce would give Hamas time to build up its arms toward that end," Abu Marzouk said: "It's very difficult to say after 10 years what will be on both sides. Maybe my answer right now [about recognizing Israel] is completely different to my answer after 10 years." Abu Marzouk and Shallah's views differ at this point. Whereas the concept of hudna constitutes the terms on which political negotiations are possible, Shallah rejects negotiation as such. When asked about hudna, Shallah replied: "I don't agree with Hamas's idea of a long hudna with Israel, because Israel will only use the time to make things worse." Agreement can be made "on a short-term truce for specific purposes, like getting food in to the people" (Atran and Axelrod 7). 


\section{Naturalization of Threat: Resistance by Other Means}

The refusal of political discourse is not only a derivative of the oppression of Palestinians by Israeli occupation, and of the negation of Palestinian civil rights. Like the words of Livni, Olmert, Netanyahu and others, those of Shallah and Abu Marzouk reveal additional reasons for the failure to translate resistance into political discourse.

Abu Marzouk, in the interview cited above, was asked about the first section in the Hamas Charter that cites a hadith, or saying, of the Prophet Mohammad. The charter reads:

The Day of Judgment will not come about until Moslems fight the Jews (killing the Jews), when the Jew will hide behind stones and trees. The stones and trees will say O Moslems, O Abdulla, there is a Jew behind me, come and kill him. Only the Gharkad tree would not do that because it is one of the trees of the Jews. ${ }^{12}$

In his reply, Abu Marzouk "defended the hadith as being taken out of context. The passage, he said, did not apply to all Jews - just those in Palestine."

The second section of the Charter cites passages from the "Protocols of the Elders of Zion." Marzouk commented: "The Zionists wrote it, and they said, 'No, we didn't.' [It's] linked to Zionists." When informed that the protocols were a forgery, Marzouk appeared nonplussed and said that it was the first time that he had heard this. ${ }^{13}$ Just as terror is perceived as a natural evil by some Israeli leaders, so is the project of Jewish self-determination perceived as naturally evil by some Palestinian leaders. Since the essence of Israeli sovereignty is understood as the negation of Palestinian political existence and national identity, the natural conclusion is that Israelis should be fought and exterminated.

In Palestinians' image of Israeli evil, the separation wall and fence mean an obstacle for resistance - since the targets of resistance are Israelis as such. In an interview to Al Jazeera dated 11.11.2006 Shallah says:

The istishhad (martyrdom) operations - as a strategic choice or as a choice created by the Palestinian people in order to balance the power and deterrence in a battle with an enemy, a battle that is 
unbalanced from the outset, they [the operations] exist and we will not renounce them. But, the timing of the operations and the ability to execute them - depend on the conditions on ground. In the West Bank, for example, there is the separation fence, which is an obstacle to resistance. And if it were not there - the situation would have been completely different. ${ }^{14}$

The separation wall is resisted not as annexing and oppressive but as that which halts the struggle against Israeli rule as such, that is, an obstacle to the liberation

\section{"Bad" Objects and "Good Selves" in Phantasy: Melanie Klein Revisited}

The analysis of the naturalization of evil of Israelis/Palestinians and its relation to the militarization of conflict suggests that "terrorism" and "occupation" are not only violent acts of national (individual or state) agents, but are also signifiers that play a central role in the failure of political negotiation and agreement, qua political.

Complicating the discussion of the Israeli-Palestinian relations with Melanie Klein's psychoanalytic theory will involve a translation that significantly changes the meaning of theory. ${ }^{15}$ In the analysis of the naturalization of evil of Israelis and Palestinians presented below, Kleinian theory is extrapolated into the political arena, whereby three of its main essentials are undermined: its reference to infants in their few first months of life (i.e., reference to pre-linguistic processes); its chronological account (i.e., an account of a progression in which "primitive" psychic states precede "normal" ones); and its universalism (i.e., its reference to biological instincts and needs). Such displacement allows for an investigation of the role of phantasy, of aggressive and libidinal ties in an analysis of the social and political realm, without their reduction, by analogy, to an infantile ego.

Klein's theory offers an elaborate phenomenology of a "primitive" mental state, termed the "schizoid-paranoid position." It is characterized by an intolerable experience from which the self cannot relieve itself; and, as a 
defense, experiences itself as split from its "bad" parts. These "bad" parts are located in an external object that is then feared as a "bad" object. The self attempts to expel the "bad" object in phantasy, but the "bad" self is transformed through this phantasy, so that the object is eventually experienced as the "bad" self. In her reading of Melanie Klein and of Klein's successors, Jacqueline Rose elaborates the distinction between phantasy as a mental expression of needs and instincts, and between phantasy as an interpretation, or subjective production. It is the latter notion, claims Rose, that accords with the "impossibility of assigning some simple origin to destruction", characteristic of Klein's dictum (141). "Bad" objects are thus not a derivative of an aggressive instinct, but are rather constituted as such in a play of projections and introjections giving rise to grandiose, omnipotent experiences of self and object, and to related persecution and annihilation anxieties.

The phenomenology of the schizoid-paranoid position can be applied to an analysis of the role of the "evil objects" in the relations between Israelis and Palestinians. We have seen that moral superiority is experienced despite the destruction brought about by the violence on each side. In Kleinian terms, we can say that the "evil" object ("occupier," "terrorist") is a product of the transformation of aggression in each side's phantasies (i.e., "a land without people"; "restoration of the past"), so that aggression is disowned, projected as the experience of the evil, persecuting Palestinian/Israeli other that is expelled and annihilated. In this process aggression is "lost" as a self-experience. Thus, each side perceives its violence as "good," i.e., as an affirmation of one's moral superiority, a sacred duty. The disavowal of aggression by Israelis and Palestinians is manifest in the fact that neither side recognizes itself in the other's signifier, which refers to its inflicted violence (the signifier "terrorism" is denied by Palestinians, whereas the signifier "occupation" is denied by Israelis). In this way, "war on terror" and "war on Israel" are experienced as self-defense, whereas their related aggression and destructiveness are, experientially, not there. 


\section{Minding the Analyst}

What is the role of psychoanalytically-informed critical theory in the analysis of the Israeli-Palestinian conflict and Israeli occupation? This question raises a more general one, i.e., how should we conceive of the relation between the psychoanalytically-informed critical theorist and his or her subjects of analysis? In importing psychoanalysis into the cultural, political domains, what happens to the role of the analyst?

These questions will be approached by a return to Jacqueline Rose's The Question of Zion. The text shares many similarities to the discourse of the extreme political left in Israel. Thus, its exploration is also an attempt to understand certain aspects of the political ineffectiveness of advancing a resolution to the Israeli-Palestinian conflict and to Israeli occupation.

"The birth of a nation" claims Rose "might be cause for celebration; it might be cure. But written across the heart of the narrative, as something it cannot quite forget, is a counsel of despair" (Rose 1040-1041). At the heart of the Zionist narrative, resides a despair that is semi-conscious to the Zionist real and metaphoric agent: "Theodor Herzl was a depressive" (1042). Depression is not the only pathological mental state, it alternates with manic states that seem to defend against it - it was mania that Herzl experienced when writing Der Judenstaat. Herzl's "sense of losing his mind," looking as though he is "suffering a psychotic shock" or "suffering from a terrible disease" (1050-1052), becomes an allegory of the denial of depression that finds its way back into consciousness on rare occasions - or, more severely, becomes embodied. Illness is not embodied only in Herzl, that is, the disease is not a personal one:

The depression of Zionism is not, however, confined to the creative mania of Herzl alone. In January 1902 Weizmann wrote to Leo Motzkin: "[My health] is not good. As a matter of fact I went to see the doctor yesterday. He diagnosed neurasthenia and weakness of the respiratory organs. Uebermüdung und Ueberreizung (overfatigue and overexcitement)." (1058-1059) 
These physical symptoms and weakness are symptomatic - yet neither of "Jewish self-hatred," nor of "a recycling of anti-Semitic stereotypes" (1062). Rather, they "testify to a form of recognition. Too much was being demanded (excitement, or overstimulation, wears the spirit thin). In order for this dream to be brought to fruition, too much — violently - would have to be performed" (1058). The dream - Herzl's dream, which is also the Zionist dream - is thus a manic dream, essentially destructive for its dreamer and for its Palestinian "other." Much of what follows is presented as proof.

Yet, when a diagnosis is not taken literally, i.e., when its metaphoricity is lost in interpretation, there seems to be not much that can contradict it. In this way interpretation becomes alien to the texts that it reads - it is not only ironic, but tells a truth, whereas words of key players are sometimes brought up merely to be negated. "The captain weeps," writes Weizmann to his fiancée in the same letter quoted above; "The man setting out to war weeps" (1058). These words are interpreted as a fundamental moral ignorance, a hubris from which Zionism never recovered: "Zionism would ask too much. To achieve the dream of Zion, you would have to place yourself in a psychically unoccupiable place-high or low, exalted or in despair" (1068). It is this mental reason, which is also a moral reason, of which Zionism is ignorant that makes the realization of Zionism possible only in a dream state, a State in dreams: "Zionism could be forged only in a state 'beyond consciousness' (as in Altneuland, the making of the nation cannot be grasped by the conscious mind)" (1069).

Zionism and its history are thus approached not only in an attempt to trace the different, conflicting and ambivalent ways by which the nation imagines itself, but rather as a dream, one dream. In this making of a dream, a Zionist dream, the stage is set for dismissing "Zionist" self-knowledge as an infantile (un)consciousness. "Precisely because Zionism had to make itself out of nothing - create a unity, a language, a homeland where there was none beforeit knows itself as a child of the psyche, a dream, a figment of the brain," writes Rose (1088). It is as if a re-take on the myth something out of nothing is 
performed here: "land without a people to a people without a land" is replaced by a myth of "consciousness without a subject to a subject without consciousness."

When Zionism becomes a dream, it is (psycho)analyzed in isolation - no politics, no wars, no internal struggles, and much proof of its unconscious state. In Negativity in the Work of Melanie Klein Rose raises a cardinal question on the place of the (psycho)analyst that is of the greatest relevance here, in the discussion of the place of the cultural analyst: "What problems must it pose for an analytic school to situate itself in the place of an infant to whom interpretation is by definition unwelcome and who is fantast and fool?" (147). One of the problems of such positioning as it emerges in The Question of Zion is the splitting between "good" Zionists and "bad" Zionists. The words of the former are not interpreted as part of a real, divergent, conflictual, ambivalent multiplicity of voices, but as an exception, a divergence, a clear, pure, moral moment when reason attempts to penetrate the collective dream, to no avail. When the truth is told about the reality of the Zionist unconscious, and at the same time about Zionism's moral status as a child, "good" Zionist voices are idealized, kept apart from the rest, elevated as the voices of prophets at the gate. It is often as prophecies that the words of the extreme political left as well are voiced in Israeli public discourse. ${ }^{16}$ This is not merely a matter of literary style - what is missing in prophetic discourse is the possibility of relating to evil and violence from the stance of the psychoanalyst, i.e., a stance that is neither "external" nor "internal" to the subjects in analysis, but is reflectively critical of the loss of metaphoricity of the "walls" that constitute "outside" and "inside" as split. This absence of a (psycho)analytic stance is sometimes related to an inaccurate diagnosis that undermines the possibility of cure. In agreement with Edward Said, for example, Rose writes: "Seeing the enemy as outside threat only, Israel was sowing the seeds of long-term damage within" (2007, p. 1153). Said's words in "Zionism from the Standpoint of Its Victims" convey a similar notion: "Everything that did stay to challenge Israel. . . was viewed not as something there, but as something outside Israel and Zionism bent on its destruction-from the outside" (1154-1155). 
Does Israel see its enemies as "outside threat only"? In other words, is the signifier "Palestinian" foreclosed, in Lacanian terminology, in the Israeli unconscious? ${ }^{17}$ It seems that a Kleinian description of the schizoid-paranoid position allows us to better account for the complexities of the Israeli-Palestinian unconscious since it captures, as Rose so eloquently observes in Negativity in the Work of Melanie Klein, "the impossibility of assigning a simple origin to destruction" (141). The Israeli-Palestinian case is an example of such impossibility, where destruction is supported by phantasy in complex dynamics of projections and introjections. The impossibility of assigning a simple origin to destruction also means that an analysis of personal and/or cultural unconscious phantasies does not tell the whole truth about destruction and that the truth that it tells is part of the cultural arena in which phantasies, cultural and inter-cultural, are forged, and in which interpersonal, national, trans-national and inter-national destruction plays a part. In psychoanalysis, no one is without phantasy, i.e., no one is outside the dream, and no one is always awake. A psychoanalytic reading "otherwise", in Rose's terms, would thus aim " to demonstrate the triumph of the unconscious over all attempts at hermeneutic and therapeutic control" (128). As such, it would not lose sight of the problem stated by Rose, of how to transmit knowledge of the unconscious without effacing its force (131).

Recognizing the difference between the psychotic state, in which foreclosure is a mark, and the schizoid-paranoid state, in which signification plays a prominent role, is important for understanding destruction and evil in the Israeli-Palestinian context. Seeing the "evil object" as a sign of a foreclosure means that for Palestinians, Israel as a signifier of national identity and state is symbolically non-existent, and that the same is true for Israelis vis-à-vis the signifier Palestine. It also means that there is only one "good" perspective for reading Israelis' and Palestinians' ideas, narratives and practices of selfdetermination, i.e., the perspectives of their victims. But, as suggested above, the case is more complicated (if it were not, violence would have probably "resolved" the conflict long ago). It involves different and converging phantasies and their disavowals, projections and introjections that give rise to "good" and "bad" part- 
objects and part-selves - a dynamic that, contrary to foreclosure, attests to the massive investment in signification (mis)interpretation and (mis)understanding.

Freud's theorization of the nature of group violence suggests that destruction does sometimes have simple origins. In a letter to Einstein, answering the latter's query Why War? Freud writes of the prominent role of violence in the formation of society:

It is a general principle, then, that conflicts of interest between men are settled by the use of violence. This is true of the whole animal kingdom, from which men have no business to exclude themselves. In the case of men, no doubt, conflicts of opinion occur as well which may reach the highest pitch of abstraction and which seem to demand some other technique for their settlement. That, however, is a later complication. (204)

Violence (Freud here follows Hobbes), is the stuff from which human social ties are forged; violence over difference of opinions is only secondary: "Right is the Might of the Community." Whether this is true or not, in societies haunted by annihilation anxiety, violence or threat of violence, this tends to feel like the case - as shown in the analysis of the Israeli-Palestinian politicization of might and militarization of right. If Freud is right, then we do not have to assume the existence of an essential moral evil of the Israeli/Palestinian agents in the analysis of their "regress." Rather, the wall can be seen as an attempt to defend against yet worse scenarios for all involved. We also do not have to resist the agents' childlike senselessness - there is no childless adult in the Freudian world - in order to contemplate the future of its "illusion." Such resistance, shows Klein, is only possible in phantasy. Freud's dictum thus escapes moralism and utopianism: "It is my opinion," Freud writes to Einstein, "that the main reason why we rebel against war is that we cannot help doing so. We are pacifists because we are obliged to be for organic reasons. And we then find no difficulty in producing arguments to justify our attitude" (214). Freud names the fundamental psychological condition by which "transition from violence to this new right or justice" can take place: "the union of the majority must be a stable and lasting 
one" (205). Maybe what is missing today in psycho/cultural analysis of the IsraeliPalestinian situation are phantasies that will approach the powers of the majorities amidst destruction and deepening fragmentations, while drawing these powers towards a politics that would be worthy of its name.

\footnotetext{
${ }^{1}$ Yuval Yoaz "Livni: The Separation Fence - The Future Border of Israel." Ha'aretz 12.01.05 in Arieli 329.

2 Interview with Army Radio. December 4, 2007 in Arieli 330.

${ }^{3}$ In an interview on "Mishal Kham" program on Israel's Channel Two 02.07.06 in
} Arieli 329.

${ }^{4}$ Amos Harel "West Bank not Done and Never Will be, It Seems." Ha'aretz 14.07.09.

${ }^{5}$ Lily Galili "An alien from the establishment." Ha'aretz 10.03.03.

${ }^{6}$ Aviram Zino "Ehud Ulmert: There is a Moral Abyss Between us and Our Enemeis." Ynet, 05.07,2005.

${ }^{7}$ The Hebrew word "chalal" often used when referring to victims of terror also denotes a person who has fallen in battle.

${ }^{8}$ The Hebrew word "gvul" means both a limit and border. It is used here by Netanyahu in the dual sense.

${ }^{9}$ Israel's Channel Two News 04.25.12

10 Minisitry of Defence website "Israel's Security Fence", "Humanitarian Concerns" http://webcache.googleusercontent.com/search?q=cache:CB90IAFobgJ:http://www.securityfence.mod.gov.il/pages/eng/Humanitarian.htm\%2Baim \%2Bto\%2Bbalance \%2Bthe\%2Bimperative \%2Bto\%2Bprotect\%2Binnocent\%2Bliv es\&rls=com.microsoft: ${ }^{*}$ oe $=$ UTF8\&startIndex=\&startPage=1\&rlz=1|7ADFA en|L483\&hl=iw\&ct=clnk

${ }^{11}$ Larry Cohler-Esses "Hamas Wouldn't Honor a Treaty, Top Leader Says." The Forward 04.19.12.

12 From Hamas charter, cited in Larry Cohler-Esses (see note 11)

${ }^{13}$ Larry Cohler-Esses (see note 11)

${ }^{14}$ http://www.seamzone.mod.gov.il/Pages/Heb/default.htm

${ }^{15}$ What Jacqueline Rose terms "reading otherwise": "a strategy of reading which heads past the most immediate or professionally received meanings of the writer." Referring to rereading Melanie Klein, Rose suggests that "Klein produced 
a theory which, because of what it was trying to theorize, could not, by definition, contain or delimit itself." (128)

${ }^{16}$ Yizhak Laor, for example, a poet and publicist, wrote on Netanyahu's recent proposal to hold early elections: "There is no opposition, certainly not on the left, that will mark May 8 as the Festival of Fools of which the slogan is "We are all idiots," with a cartoon of Kadima MK Shaul Mofaz on the lapel." Yizhak Laor. "May 8, Festival of Fools." in Ha'aretz 09.05.2012.

${ }^{17}$ Bernard-Henri Levy presents an account of the relation between Zionism and its "other" in a debate with Slavoj Zizek, held in New York Public Library, 09.16.08. Levy's portrayal of such relations is opposite of that of Said. Whereas for Said, everything that challenges Israel is perceived as an enemy attacking from the outside, for Levy challenges to Israel are admirably faced by incorporating opposition into politics: "Israel is the only country in the world where you have, in the political debate and in the parliament, members who are antiZionism. You have some political parties of the extreme left, you have Arab party, who believe the creation of Zionism is a mistake, that the creation of Israel is a mistake. And not only are they tolerated, they are members of the debate." See "Violence \& The Left in Dark Times: A Debate." http://fora.tv/2008/09/16/Violence the Left in Dark Times A Debate It is interesting to think of Israel as the "good" and "bad" object as it emerges in these discourses - what they incorporate "about" Israel, and what they leave out.

\section{Works Cited}

Arieli, Shaul. "A wall of Folly." People \& Borders. Israel: Tach Print, 2011. 326-60. Print.

Atran, Scott and Robert Axelrod. "Interview with Ramadan Shallah, Secretary General, Palestinian Islamic Jihad (Damascus, Syria, December 15, 2009)." Perspectives on Terrorism. 4.2 (2010): 3-9. Print.

Freud, Sigmund. "Why War?" The Standard Edition of the Complete Psychological Works. XXII. London: Hogarth Press, 1955. Print.

Halperin, Eran, Daniel Bar-Tal, Keren Sharvit, Nimrod Rosler, and Amiram Raviv. "Socio-Psychological Implications for An Occupying Society: The Case of Israel." Journal of Peace Research (2010) 47. 59-70. Print. 
Mukamel, Maya. "Look What You Made Me Do! On Separation Walls as a Political Policy." (a): The Journal of Culture and the Unconscious. VIII.1 (2009-2010): 47-56. Print.

Rose, Jacqueline. "Negativity in the Work of Melanie Klein." Rpt. in Reading Melanie Klein. Eds. Lindsey Stonebridge and John Phillips. London and New York: Routledge, 1998. 126-59. Print.

---. The Question of Zion. Princeton University Press: Kindle Edition, 2007. Print. 